\title{
The longicorn beetle tribe Cerambycini Latreille, 1802 (Coleoptera: Cerambycidae: Cerambycinae) in the fauna of Asia. 2. A new or little-known species of the genus Neocerambyx J. Thomson, 1861
}

\author{
ЖКуки-дровосеки трибы Cerambycini Latreille, 1802 \\ (Coleoptera: Cerambycidae: Cerambycinae) фауны Азии. 2. Новый \\ и малоизвестные виды рода Neocerambyx J. Thomson, 1861
}

\author{
Alexandr I. Miroshnikov ${ }^{1,2}$ \\ А.И. Мирошников
}

${ }^{1}$ Russian Entomological Society, Krasnodar, Russia. E-mail: miroshnikov-ai@yandex.ru
${ }^{2}$ Sochi National Park, Moskovskaya str., 21, Sochi, Krasnodar region 354002, Russia
${ }^{1}$ Русское энтомологическое общество, Краснодар, Россия.
${ }^{2}$ Сочинский национальный парк, ул. Московская, 21, Сочи, Краснодарский край 354002, Россия.

KEY WORDS: Coleoptera, Cerambycidae, Cerambycini, Neocerambyx, new species, India, China, Laos, Vietnam, Western Malaysia.

КЛЮЧЕВЫЕ СЛОВА: Coleoptera, Cerambycidae, Cerambycini, Neocerambyx, новый вид, Индия, Китай, Лаос, Вьетнам, Западная Малайзия.

ABSTRACT. A new species, Neocerambyx bakboensis sp.n., is described from northeastern Vietnam. New data on N. pellitus (Hitzinger in Breuning et Hitzinger, 1943) are given, including its female described for the first time. Various records of $N$. grandis Gahan, 1891 and N. katarinae Holzschuh, 2009 are presented and discussed from India, China, Laos or Vietnam, and their distribution are partially rectified.

How to cite this article: Miroshnikov A.I. 2018. The longicorn beetle tribe Cerambycini Latreille, 1802 (Coleoptera: Cerambycidae: Cerambycinae) in the fauna of Asia. 2. A new or little-known species of the genus Neocerambyx J. Thomson, 1861 // Russian Entomol. J. Vol.27. No.1. P.33-39. doi: 10.15298/rusentj.27.1.05

PЕЗЮМЕ. Описан новый вид Neocerambyx bakboensis sp.n. из северо-восточного Вьетнама. Приведены новые данные о N. pellitus (Hitzinger in Breuning et Hitzinger, 1943), в том числе впервые описана его самка. Обсуждены различные находки N. grandis Gahan, 1891 и N. katarinae Holzschuh, 2009 в Индии, Китае, Лаосе и Вьетнаме и отчасти уточнено их распространение.

\section{Introduction}

The genus Neocerambyx J. Thomson, 1861 is widely distributed and covers South, East and Southeast Asia. Taking into account a new form described here, it contains no less than 11 species. However, this genus and Massicus Pascoe, 1867, which is very similar to it, require a detailed revision [Miroshnikov, 2017].
The present paper describes a new species from northeastern Vietnam, provides morphological features of the female of Neocerambyx pellitus (Hitzinger in Breuning et Hitzinger, 1943) for the first time and gives an accurate record of this species from Western Malaysia, the southernmost in its distribution area. Besides this, the distributions of Neocerambyx grandis Gahan, 1891 and N. katarinae Holzschuh, 2009 in India, China, Laos and Vietnam are discussed, based both on new material studied and an analysis of literature data.

The material treated in this work belongs to the following institutional and private collections: BM Bishop Museum (Honolulu, USA); MSNM - Museo Civico di Storia Naturale (Milano, Italy); cAM — collection of Alexandr Miroshnikov (Krasnodar, Russia); cCH collection of Carolus Holzschuh (Villach, Austria); cSM - collection of Sergey Murzin (Moscow, Russia).

Neocerambyx bakboensis Miroshnikov, sp.n. Figs 1-2, 7, 10, 12, 14, 16, 18, 20.

MATERIAL. Holotype $\sigma^{7}$ (cAM) (Fig. 1), NE Vietnam, Cao Bang, 09.2017 (local collector). Paratypes: 10, 1 우 (cAM) (Fig. 2), same label as holotype.

DIAGNOSIS. This new species seems to be especially similar to N. pellitus, but differs clearly by the much less strongly developed recumbent light setation of the dorsum, which weakly conceals the dark coloration of the integument at least of the elytra, as in Figs 1-2 (cf. Figs 3-4, 6); the shorter antennae in both sexes, but especially so in the male, as in Figs 1-2 (cf. Figs 3-4, 6); the shape of the scutellum apically, as in Figs 14, 16 (cf. Figs 15, 17); the somewhat peculiar sculpture of the submentum and, partly, prosternum; some features of the male, in particular, the slightly narrower pronotum, the somewhat peculiar sculpture of its disc, as in Fig. 7 (cf. Figs 8-9), 

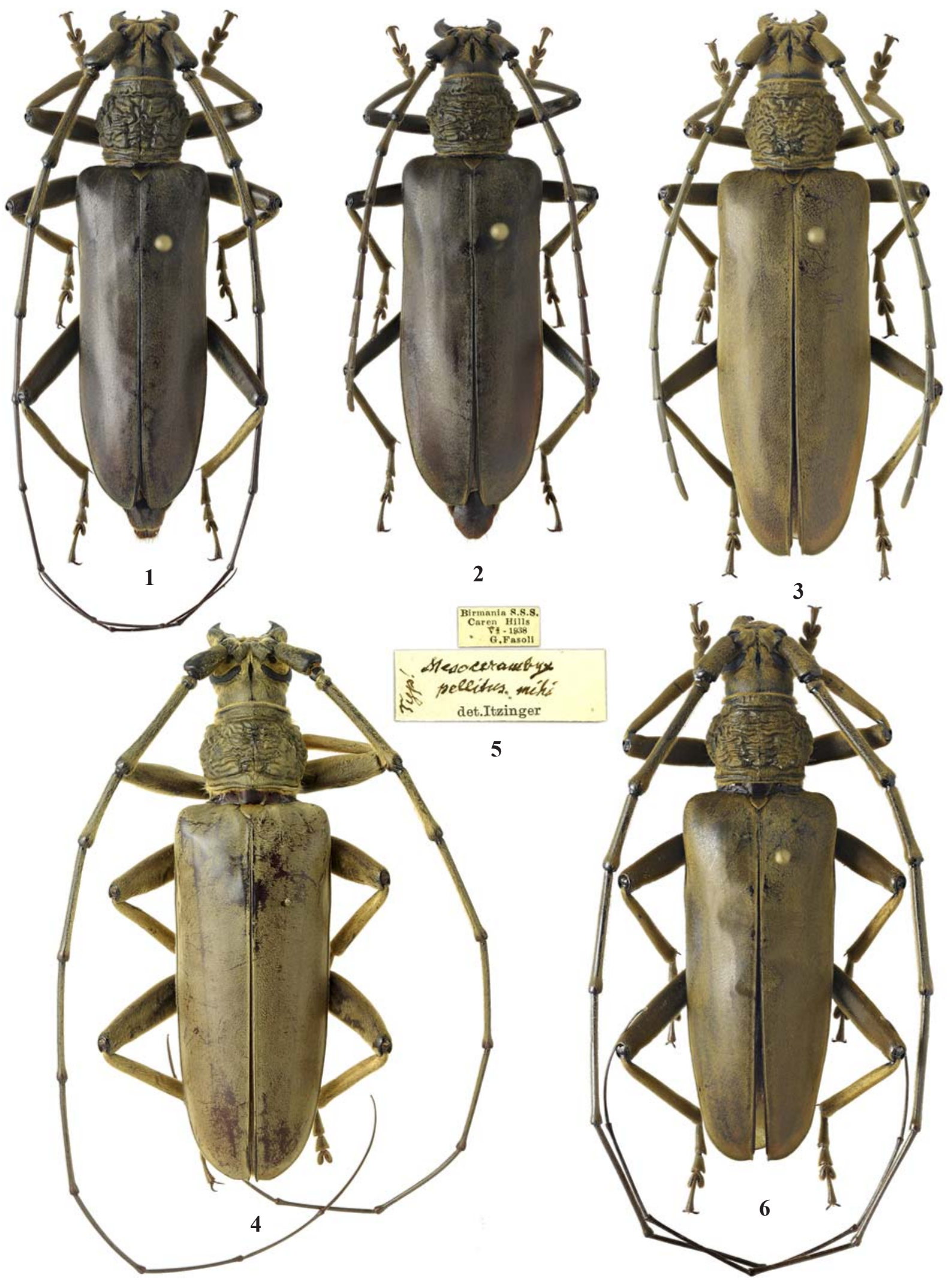

Figs 1-6. Neocerambyx spp., habitus and labels: 1-2 - N. bakboensis sp.n.; 3-6-N. pellitus; 1, 4 - holotypes, males; 2 - paratype, female; 3, 6- female and male, respectively (Western Malaysia, Bukit Fraser) (4-5 - photographs by Michele Zilioli).

Рис. 1-6. Neocerambyx spp., общий вид и этикетки: 1-2 - N. bakboensis sp.n.; 3-6 - N. pellitus; 1, 4 - голотипы, самцы; 2 паратип, самка; 3, 6 - самка и самец, соответственно (Западная Малайзия, Букит Фрейзер) (4-5 - фотографии Микеле Зилиоли). 
the structure of the apical part of the penis and tegmen, as in Figs 18, 20 (cf. Figs 19, 21), as well as the last (visible) tergite of the female which is weakly emarginate apically, as in Fig. 12 (cf. Fig. 13); the smaller body sizes; and some other traits.

DESCRIPTION. Body length 49.3-53.7 mm, humeral width $13.4-14.5 \mathrm{~mm}$, thereby holotype largest. Head, pronotum, basal antennomeres, almost completely or mostly prosternum black; legs black-brown or mainly black; elytra, meso- and metasterna, visible part of abdomen, apical antennomeres, at least partly prosternal process dark reddish brown and reddish brown tones.
Head with moderately developed antennal tubercles; with a very deep and pretty wide, median groove between eyes and partly on vertex; with a very dense and confluent puncturation dorsally; eyes moderately convex; longitudinal diameter of lower lobe of eye 1.2 or 1.35 times as long as genae in male and female, respectively; submentum with a very coarse transverse fold (in N. pellitus, submentum with two coarse transverse folds); neck ventrally and laterally with very clear and sharp transverse folds; antennae of male significantly longer than body, reaching beyond apex of elytra by antennomere 8 , in female very clearly not reaching the apex of elytra;

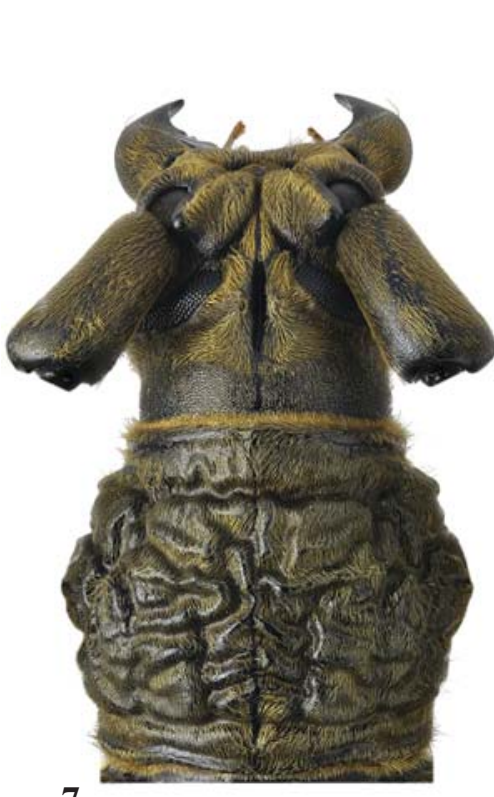

7

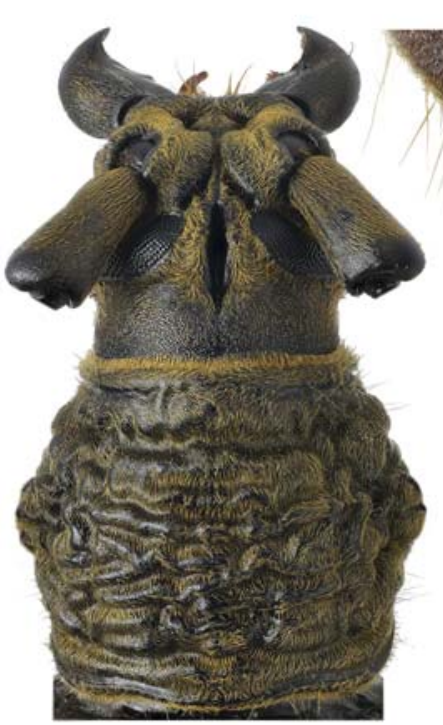

10

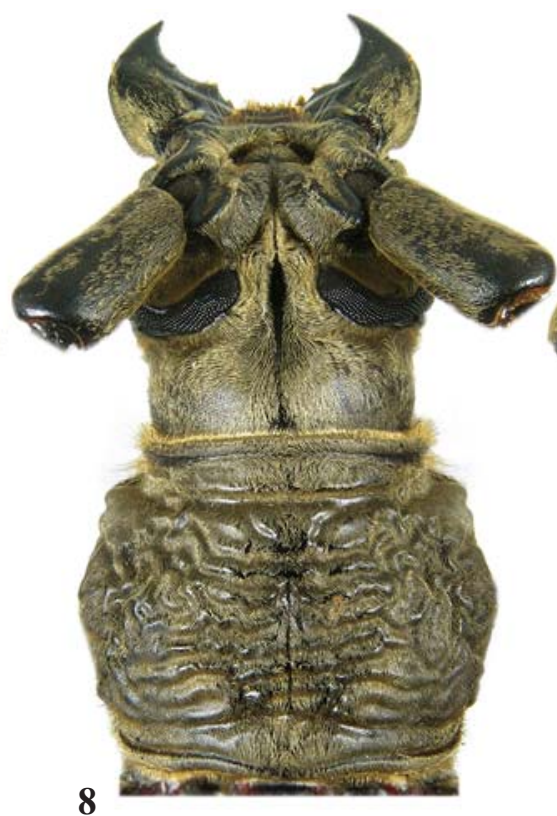

9

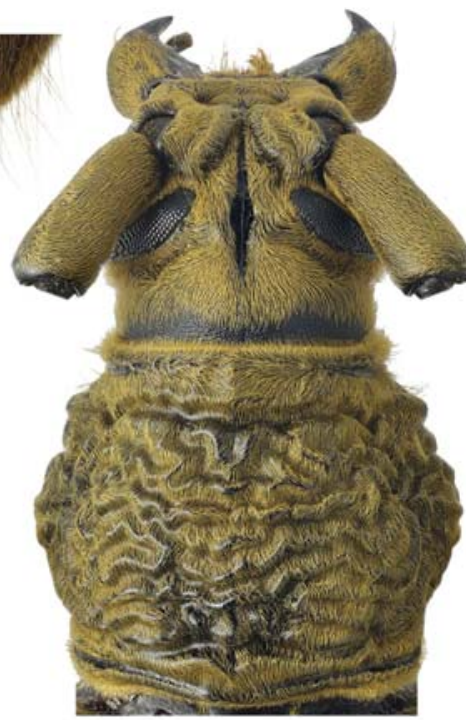

11

16

17

Figs 7-17. Neocerambyx spp.: 7, 10, 12, 14, 16 - N. bakboensis sp.n.; 8-9, 11, 13, 15, 17 - N. pellitus; 7-8, 14 - holotypes males; 9 , 15 - male (Western Malaysia, Bukit Fraser); 10, 12, 16 - paratype female; 11, 13, 17 - female (Western Malaysia, Bukit Fraser); 7-11 head and pronotum, dorsral view; 12-13 - apex of last (visible) tergite, dorsral view; 14-17 — scutellum (8 — photograph by Michele Zilioli).

Рис. 7-17. Neocerambyx spp.: 7, 10, 12, 14, 16 - N. bakboensis sp.n.; 8-9, 11, 13, 15, 17-N. pellitus; 7-8, 14 - голотипы, самцы; 9, 15 - самец (Западная Малайзия, Букит Фрейзер); 10, 12, 16 - паратип, самка; 1, 13, 17 - самка (Западная Малайзия, Букит Фрейзер); 7-11 — голова и переднеспинка, сверху; 12-13 — вершина последнего (видимого) тергита, сверху; 14-17 — щиток (8 фотография Микеле Зилиоли). 


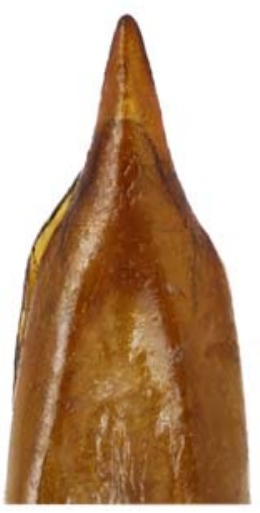

18

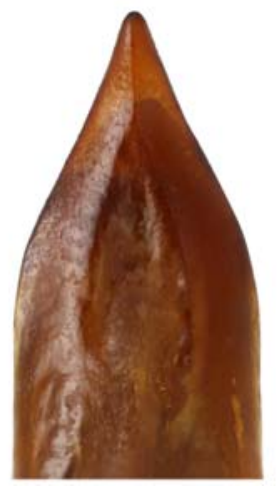

19

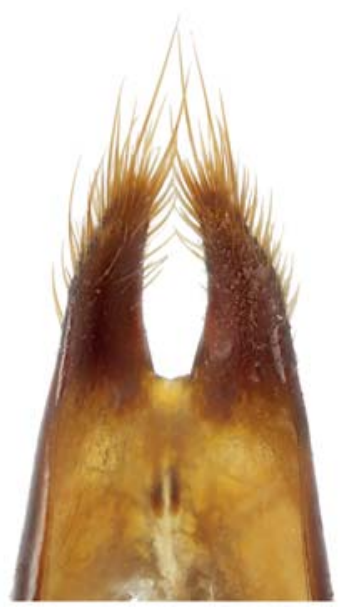

20

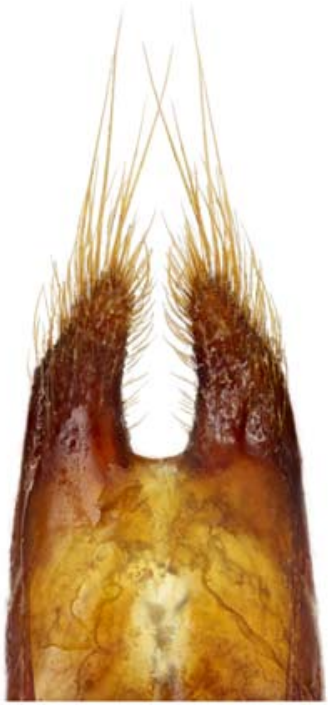

21

Figs 18-21. Neocerambyx spp.: 18, $20-N$. bakboensis sp.n., paratype male; 19, 21 - N. pellitus, male (Western Malaysia, Bukit Fraser); 18-19 - apex of penis, ventral view; 20-21 - apical part of tegmen, ventral view.

Рис. 18-21. Neocerambyx spp.: 18, 20 - N. bakboensis sp.n., паратип, самец; 19, 21 - N. pellitus, самец (Западная Малайзия, Букит Фрейзер); 18-19 - вершина пениса, снизу; 20-21 — вершинная часть тегмена, снизу.

length ratio of antennomeres 1-11 in male (holotype taken as an example), $32: 5: 59: 36: 53: 56: 54: 52: 47: 42: 60$, in female, $23: 4: 36: 22: 30: 28: 26: 21: 18: 14: 17$; antennomere 1 without coarse sculpture, only with a relatively small dense puncturation, apical external angle rounded; antennomere 2 strongly transverse.

Pronotum 1.15-1.18 or 1.21 times as wide as long in male and female, respectively (in male of $N$. pellitus, 1.28-1.3 times); at base clearly wider than at apex; on disc slightly convex, with coarse, irregular (in male) or mainly transverse (in female) folds, as in Figs 7, 10.

Scutellum triangular, as in Figs 14, 16.

Elytra 2.46-2.53 times as long as humeral width; slightly narrowed towards apex or about parallel-sided in male and female, respectively; with a very small and very dense puncturation; apical external angle obtuse, sutural angle with a very short denticle.

Prosternum with a sharp, deep, transverse groove in front of middle, with rough, predominantly irregular, more or less short folds and wrinkles in front of it (in N. pellitus, in this area, at least partly, with rough transverse folds) and with coarse irregular folds behind groove; prosternal process with a clear or very well-expressed apical tubercle; mesosternal process without tubercle dorsally, between coxae very clearly wider than prosternal process; meso- and metasterna and sternites with a small dense puncturation; metasternum with a very sharp median groove; last (visible) sternite in both sexes widely rounded apically, but in female, in addition, barely emarginate in the middle; last (visible) tergite in both sexes with a shallow emargination at apex (in female of $N$. pellitus, last visible tergite very clearly emarginate apically), but in male more strongly expressed.

Legs moderately long; femora pretty robust in male; tarsomere 1 subequal to tarsomeres 2 and 3 combined in length.

Recumbent setation golden yellow, the most dense mainly on venter and legs, the least dense on elytra, resulting in their looking dark (vs. elytral setation, as well as general setation of dorsum much denser, resulting in its looking light in $N$. pellitus)

ETYMOLOGY. The name of this new species is related to the historical and geographical region of Vietnam, Bắc bộ (in Vietnamese) (Tonkin in French) which it inhabits.

DISTRIBUTION. Northern Vietnam.

\section{Neocerambyx pellitus}

(Hitzinger in Breuning et Hitzinger, 1943)

Figs 3-6, 8-9, 11, 13, 15, 17, 19, 21.

Mesocerambyx pellitus Hitzinger in Breuning et Hitzinger, 1943: 37. Type locality: Burma [now Myanmar], Caren Hills [= Karen Hills] (according to the original description and the label of the holotype).

Neocerambyx pellitus: Hüdepohl, 1990: 254, 255 (Burma, Thailand, Malaysia).

MATERIAL. Holotype by monotypy, $\sigma^{7}$ (MSNM) (photograph; Fig. 4), "Birmania S.S.S., Caren Hills, VI.1938, [leg.] G. Fasoli" / "Type! Mesocerambyx pellitus mihi, det. Itzinger (sic)" (Fig. 5); 10", 3 ㅇ (cAM) (Figs 3, 6), Western Malaysia, Pahang, Bukit Fraser [= Fraser's Hill], $3^{\circ} 43$ 'N / 101 $44^{\prime} \mathrm{E}, 1000-1300 \mathrm{~m}$, 9-12.05.2007, leg. V. Tuzov / Neocerambyx pellitus (Hitzinger in Breuning et Hitzinger, 1943) ( $0^{7}$ or + , respectively), det. A. Miroshnikov 2017.

REMARKS. This species was described from a single male. Female features are given here for the first time.

The measurements of male from Western Malaysia: body length $63.0 \mathrm{~mm}$, humeral width $17.9 \mathrm{~mm}$. Body length of the holotype is $75 \mathrm{~mm}$.

DESCRIPTION OF THE FEMALE (Figs 3, 11, 13, 17). Closely resembles a male. Body length $57.8-60.2 \mathrm{~mm}$, humeral width $16.0-16.9 \mathrm{~mm}$.

Head with moderately developed antennal tubercles, like in male; longitudinal diameter of lower lobe of eye 1.14-1.21 times as long as genae (in male, this diameter 1.1 times as long as genae, at least so in specimen from Western Malaysia); antennae slightly or noticeably not reaching the apex of elytra; length ratio of antennomeres 1-11 (one of the females taken as an example), $30: 5: 41: 27: 40: 39: 37: 33: 28$ : 
21 : 25; antennomere 1 like in male, with a small dense puncturation, apical external angle rounded.

Pronotum 1.21-1.27 times as wide as long; on disc mainly with transverse folds, like in male, as in Fig. 11.

Scutellum rounded apically (in male narrower at apex).

Elytra 2.45-2.48 times as long as humeral width (2.43 or 2.44 times in male from Western Malaysia and male holotype, respectively); sutural angle with a short denticle, like in male.

Last (visible) sternite widely rounded apically, but, in addition, slightly emarginate in the middle; last (visible) tergite with a well-developed emargination at apex, as in Fig. 13.

Femora slenderer than in male.

Recumbent light setation like in male, as in Figs 3, 11 .

DISTRIBUTION. Ever since its original description [Hitzinger, 1943], this species seems to have only once been cited in the literature, except for Myanmar recorded also from Thailand and Malaysia [Hüdepohl, 1990]. The latter author obviously meant Western Malaysia, but he failed to provide precise localities. Above is the southernmost accurate locality of $N$. pellitus, based on pertinent material from Western Malaysia.

Neocerambyx grandis Gahan, 1891 Figs 22-25.

Neocerambyx grandis Gahan, 1891: 20. Type locality: N. India, Allahabad (according to the original description). Gahan, 1906: 125; Aurivillius, 1912: 46; Gressitt, Rondon, 1970: 58 Hua, 1984: 69; Hüdepohl, 1990: 254, 255; Hua, 2002: 218; Hua e al., 2009: 174 (China, part.); Löbl, Smetana, 2010: 161; Weigel, 2012: 407, Taf. 26, Abb. b; Nga, Long, 2014: 19 (record requires clarification; see below); Nga et al., 2014: 436 (record requires clarification; see below); Kumawat et al., 2015: 7896, fig. 49, 7899 (wrong determination, at least partly; see below); Kariyanna et al., 2017: 33 .

MATERIAL. 107 (BM), "X. Khouang, 30.04.[19]64" / "Laos: Ban Theuong, $18 \mathrm{~km}$ NW of Xieng Khouang, 1035 m" / "J.A Rondon Collection Bishop Mus." / "Neocerambyx grandis Gahan, J.L. Gressitt det. 196[?]"; 1 \% (BM), "Van Heua, 16.03.[19]66" "Laos: Vientiane Prov., Ban Van Eua, 16.03.1966"; $10^{7}$ (cSM) Laos, Luang Namtha Prov., Muang Sing, 750 m, 23.03-5.04.2010, leg. S. Murzin / Neocerambyx grandis Gahan, 1891, $0^{7}$, det. A. Miroshnikov 2017; $20^{7}$ (cAM) (Fig. 22), Laos, Houa Phan Prov., Phou Pane Mt., $20^{\circ} 11$ ' N / 104 $00^{\circ} \mathrm{E}, 2060 \mathrm{~m}, 05.2017,06.2017$ (local collector) / Neocerambyx grandis Gahan, 1891, O', det. A. Miroshnikov 2017; 1 ( (cAM) (Fig. 23), Vietnam, Kon Tum Prov., Kon Plong Distr., Dak Khe River, 1443'20"N / 108 $18^{\prime} 58^{\prime \prime E}, 1030$ m, 8-23.04.2015, at light, leg. D. Fedorenko / Neocerambyx grandis Gahan, 1891, 옹 det. A. Miroshnikov 2017.

REMARKS. This species was described from northern India [Gahan, 1891]. Later it was recorded from Laos [Gressitt, Rondon, 1970; Hua, 1984], several southern provinces of China [Hua, 2002] and repeatedly confirmed from the northern regions of India [Gahan, 1906; Aurivillius, 1912; Gressitt, Rondon, 1970; Hüdepohl, 1990; Weigel, 2012], including those lying near the border to Myanmar [Gahan, 1906].

More recently, $N$. grandis was also recorded from four different provinces of Vietnam [Nga, Long, 2014; Nga et al., 2014]. However, the photographs presented in one of those publications [Nga et al., 2014: 431, figs 4, 7] undoubtedly depict the basal antennomeres of male $N$. katarinae Holzschuh, 2009 (see also below), but not those of $N$. grandis. Both these species (Figs 22-29) differ very clearly from each other, including the shape of antennomeres $3-5$ of the male (Figs 24, 28). In this connection, the distribution of $N$. grandis in Vietnam as outlined by Nga et al. [2014] needs clarification. At the same time, its presence in the country is confirmed here, at least so for the Kon Tum Province, based on the material I have studied (see above).
According to some unverified data, this species, in addition to other places, has been collected in Western Malaysia (Cameron Highlands).

Neocerambyx katarinae Holzschuh, 2009

Figs 26-29.

Neocerambyx katarinae Holzschuh, 2009: 285. Type locality: NE Laos, Hua Phan [= Houa Phan] Prov., Phou Pan [= Phou Pane] Mt., Ban Saleui, $1300 \mathrm{~m}, \sim 20^{\circ} 12^{\prime} \mathrm{N} / 104^{\circ} 01^{\prime} \mathrm{E}$ (according to the original description).

Neocerambyx grandis auct.: Hua et al., 2009: 43, pl. 43, fig. $5060^{7}$ (China) (non Gahan, 1891) (see below); Nga et al., 2014:. 431, figs 4, 7 (Vietnam) (non Gahan, 1891) (see above); Kumawat et al., 2015: 7896, fig. 49 (India) (non Gahan, 1891) (see below).

MATERIAL. Holotype $\sigma^{7}$, paratype $\bigcirc(\mathrm{cCH})$ (photographs); $20^{7}, 2$ (cAM) (Figs 26-27), Laos, Houa Phan Prov., Phou Pane Mt., $2060 \mathrm{~m}, 20^{\circ} 11^{\prime} \mathrm{N} / 104^{\circ} 00^{\prime} \mathrm{E}, 04.2017,05.2017,06.2017$ (local collector) / Neocerambyx katarinae Holzschuh, 2009 ( $\sigma^{7}$ or + , respectively), det. A. Miroshnikov 2017.

REMARKS. This species was described from Phou Pane Mountain, northeastern Laos [Holzschuh, 2009], and it seems to have never since been recorded in the literature.

Based on the data mentioned above in the "Remarks" section to $N$. grandis, it should be borne in mind that $N$. katarinae, almost without doubt, is widely distributed in Vietnam, like $N$. grandis. This suggestion could also be supported by the fact that both species co-occur at the same localities, for example, near the type locality of $N$. katarinae (see above the material to both species).

It is noteworthy that the male depicted by Kumawat et al. [2015: 7896, fig. 49] and originating from Pasighat, Arunachal Pradesh, northeastern India undoubtedly belongs to $N$. katarinae, not to $N$. grandis.

Besides this, I fully share the opinion of my colleague, Dr. Francesco Vitali (Musée national d'histoire naturelle de Luxembourg) [Cerambycoidea Forum, 2018 ${ }^{*}$ that the male depicted in the monograph "Iconography of Chinese Longicorn Beetles (1406 Species) in Color" [Hua et al., 2009: 43, pl. 43 , fig. $\left.5060^{7}\right]$ is also to be referred to $N$. katarinae, but not to $N$. grandis. Furthermore, the photographs of two males presented on the same Forum by some of my other colleagues [Cerambycoidea Forum, $2018^{* *, * * *}$ ] confirm the distribution of $N$. katarinae in the south of China, in particular, in Guangdong and Guangxi provinces.

Thus, the distribution area of $N$. katarinae, besides Laos, must be extended to also include Vietnam, the southern regions of China and northeastern India, and records of this species are to be expected at least in Myanmar and Thailand.

ACKNOWLEDGEMENTS. I am very grateful to James $\mathrm{H}$. Boone (BM), who kindly arranged on loan the material under his care, to Kirill V. Makarov (Moscow Pedagogical State University, Russia) for having rendered his great help in the preparation of the photographs. My special thanks are due to Michele Zilioli (MSNM) for several pictures of the holotype of $N$. pellitus and literature data he kindly shared, to Andrea Sabbadini (Milano, Italy) and Francesco Vitali (Musée national d'histoire naturelle de Luxembourg), who have generously provided with some valuable information. I am deeply indebted to Luboš Dembický (Brno, Czech Republic) has helpfully provided the photographs of the type specimens of several Neocerambyx species and to my wife Tatiana who helped a lot in the preparation of the illustrations for publication.

\footnotetext{
http://www.cerambycoidea.com/forum/topic.asp?TOPIC_ID=19521

** http://www.cerambycoidea.com/forum/topic.asp?TOPIC ${ }^{-}$ID $=17163$

${ }^{* * *}$ http://www.cerambycoidea.com/forum/topic.asp?TOPIC_ID $=18735$
} 

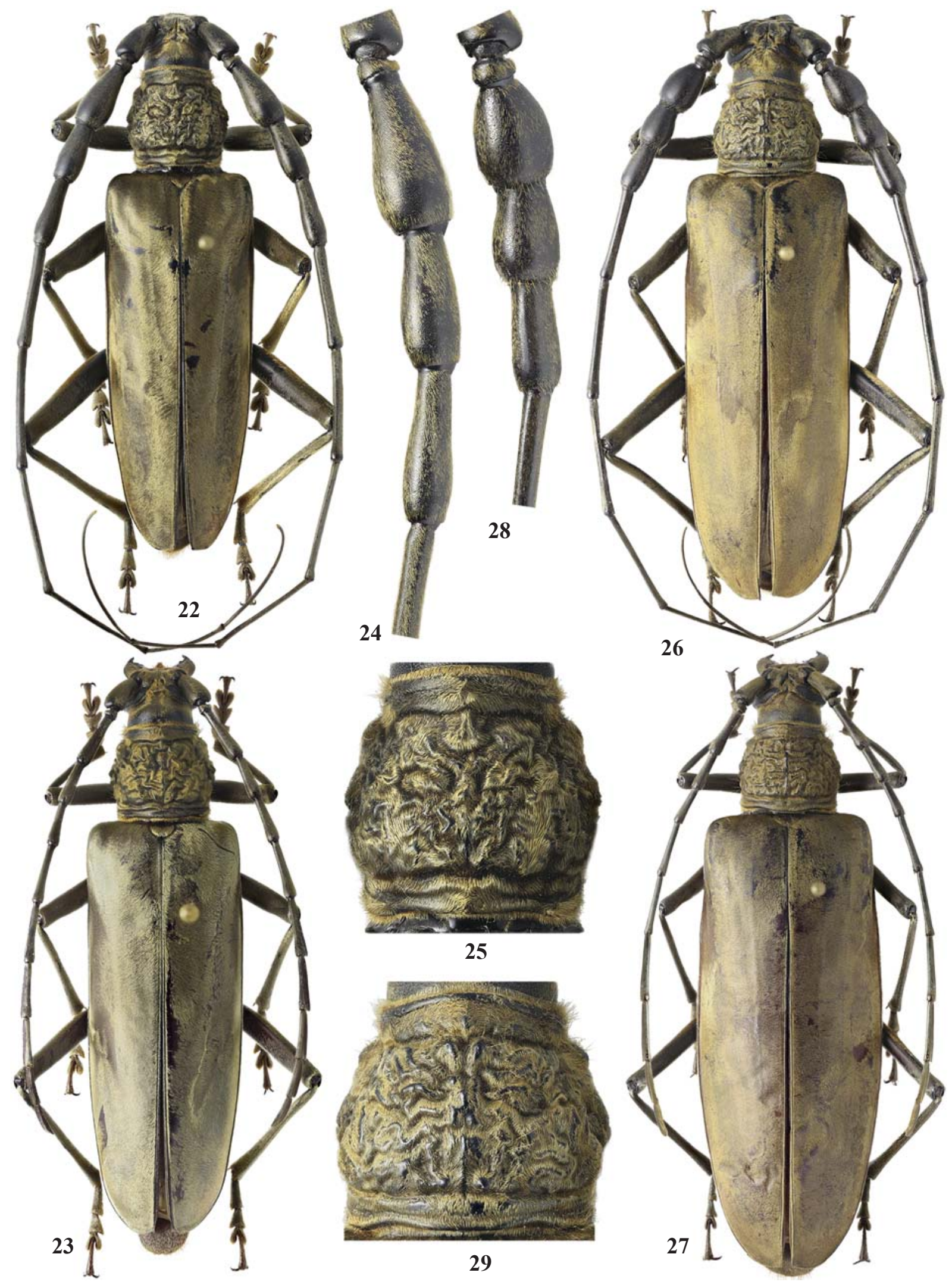

Figs 22-29. Neocerambyx spp., habitus, pronotum and right antennomeres 2-5: 22-25 - N. grandis; 26-29 - N. katarinae; 22, 2425, 28-29 - males; 23, 27 - females; 22, 26-27 - Laos, Houa Phan Province; 23 - Vietnam, Kon Tum Province.

Рис. 22-29. Neocerambyx spp., общий вид, переднеспинка и 2-5-й членики правого усика: 22-25 - N. grandis; 26-29 - N. katarinae; 22, 24-25, 28-29- самцы; 23, 27 - самки; 22, 26-27 - Лаос, провинция Хуапхан; 23 - Вьетнам, провинция Контум. 


\section{References}

Aurivillius Chr. 1912. Cerambycidae: Cerambycinae // Coleopterorum Catalogus, auspiciis et auxilio W. Junk, editus a S. Schenkling. Pars 39. Berlin: W. Junk. P.3-574.

Cerambycoidea Forum. 2018. Available at: http://www. cerambycoidea.com/forum/ (accessed 27 January 2018).

Gahan C.J. 1891. Notes on longicorn Coleoptera of the group Cerambycinae, with descriptions of new genera and species // The Annals and Magazine of Natural History. Vol.7. No.6. P.19-34.

Gahan C.J. 1906. Cerambycidae // The fauna of British India, including Ceylon and Burma. Coleoptera. Vol.1. London: Taylor and Francis. xviii +329 p.

Gressitt J.L., Rondon J.A. 1970. Cerambycids of Laos (Disteniidae, Prioninae, Philinae, Aseminae, Lepturinae, Cerambycinae) // Gressitt J.L., Rondon J.A., Breuning S. von. Cerambycid-beetles of Laos. Pacific Insects Monograph. Vol.24. Honolulu: Entomology Department, Bernice P. Bishop Museum. P.1-314.

Hitzinger K. 1943. Mesocerambyx pellitus nov. sp. // Breuning S. Hitzinger K. Cerambicidi birmani del Museo di Milano. Atti della Società Italiana di Scienze Naturali e del Museo Civico di Storia Naturale in Milano. Vol.82. P.37-39.

Holzschuh C. 2009. Beschreibung von 59 neuen Bockkäfern und vier neuen Gattungen aus der orientalischen und palaearktischen Region, vorwiegend aus Laos, Borneo und China (Coleoptera, Cerambycidae) // Entomologica Basiliensia et Collectionis Frey. Bd.31. S.267-358.

Hua L.-Z. 1984. A list of the longicorn beetles of Laos (Coleoptera: Cerambycidae). Guangzhou: Institute of Entomology, Zhongshan University. $155 \mathrm{p}$.

Hua L.-Z. 2002. List of Chinese Insects. 2. Guangzhou: Zhongshan (Sun Yat-sen) University. 612 p.
Hua L.-Z., Nara H., Saemulson [Samuelson] G.A., Langafelter [Lingafelter] S.W. 2009. Iconography of Chinese Longicorn Beetles (1406 Species) in Color. Guangzhou: Sun Yat-sen University Press. 474 p.

Hüdepohl K.-E. 1990. Über südostasiatische Cerambyciden VII. Über die Gattung Neocerambyx Thomson, 1860 (Coleoptera, Cerambycidae, Cerambycini) // Entomofauna. Zeitschrift für Entomologie. Bd.11. Hf.14. S.241-257.

Kariyanna B., Mohan M., Gupta R., Vitali F. 2017. The checklist of longhorn beetles (Coleoptera: Cerambycidae) from India // Zootaxa. Vol.4345. No.1. P.1-317.

Kumawat M.M., Singh K.M., Ramamurthy V.V. 2015. A checklist of the Long-horned Beetles (Coleoptera: Cerambycidae) of Arunachal Pradesh, northeastern India with several new reports // Journal of Threatened Taxa. Vol.7. No.12. P.7879-7901.

Löbl I., Smetana A. (eds.). 2010. Catalogue of Palaearctic Coleoptera. Vol.6. Chrysomeloidea. Stenstrup: Apollo Books. 924 p.

Miroshnikov A.I. 2017. The longicorn beetle tribe Cerambycini Latreille, 1802 (Coleoptera: Cerambycidae: Cerambycinae) in the fauna of Asia. 1. New or little-known taxa, mainly from Indochina and Borneo, with reviews of some genera // Caucasian Entomological Bulletin. Vol.13. No.2. P.161-233, pls 1-6.

Nga C.T.Q., Long K.D. 2014. A preliminary list of the subfamily Cerambycinae (Coleoptera: Cerambycidae) of Vietnam // Tap Chi Sinh Hoc. Vol.36. No.1. P.12-38.

Nga C.T.Q., Long K.D., Thinh T.H. 2014. New records of the tribe Cerambycini (Coleoptera: Cerambycidae: Cerambycinae) from Vietnam // Tap Chi Sinh Hoc. Vol.36. No.4. P.428-443.

Weigel A. 2012. Beitrag zur Bockkäferfauna von Arunachal Pradesh (Indien) mit Beschreibung einer neuen Art aus der Gattung Acalolepta Pascoe, 1858 (Insecta: Coleoptera: Cerambycidae) // Hartmann M., Weipert J. (eds.). Biodiversität und Naturausstattung im Himalaya IV. Verein der Freunde und Förderer des Naturkundemuseums Erfurt e. P.405-411, 2 figs, pls XXVXXXIII. 